\title{
Below the knee angioplasty for limb salvage in diabetic patients with critical lower limb ischemia
}

\author{
Sherif Essam Tawfik, $M D$; Sherif Omar Elkerdawy, $M D$; \\ Hesham Adel Alaa-EIdin, MD
}

\author{
Department of General Surgery, Faculty of Medicine, Ain Shams University, \\ Cairo, Egypt.
}

\section{Correspondence:}

Sherif Essam Tawfik, Department of Surgery, Faculty of Medicine, Ain Shams University, Tel.: +20101601731; fax: +20226177003

\begin{abstract}
Introduction: It is well known that atherosclerotic involvement in diabetic patients with critical limb ischemia (CLI) mainly affects below-the-knee (BTK) arteries. But the therapeutic efficacy of percutaneous transluminal angioplasty (PTA) in such patients has not been clearly defined.

Aim: This study aims to assess the clinical success and the limb-salvage rates for infragenicular angioplasty as the initial treatment of critically ischemic lower limbs in diabetic patients.

Materials and methods: From December 2006 to October 2008, a consecutive series of 64 limbs in 54 diabetic patients with critical limb ischemia (Rutherford categories 4,5,6) were treated by primary infragenicular angioplasty. Our primary end points were immediate technical success, sustained clinical improvement, haemodynamic outcome, and limb salvage rate. Secondary end points were periprocedural complications and 30-day all cause mortality.

Results: The mean age of our 54 patients was 62 years (48-70 years). The initial technical success was achieved in 94\% of procedures, with limb salvage rate of 100\%, 95\%, 89\%, and $84 \%$ at 1, 3, 6, and 12 months respectively, haemodynamic improvement of 96\%, 89\%, 79\%, and $60 \%$ at 1, 3, 6, and 12 months respectively, and sustained clinical improvement of 100\%, $95 \%, 89 \%$, and $84 \%$ at 1, 3, 6, and 12 months respectively,. The periprocedural adverse events occurred in $5(7.8 \%)$ procedures, and the 30-day all cause mortality was 1/54 (1.85\%).

Conclusion: Primary infragenicular angioplasty for limb salvage in the diabetic patient population represents an efficacious method to improve wound healing in critically ischemic limbs, taking into consideration the fragile nature and co-morbidities in such selected patient population.
\end{abstract}

Keywords: Angioplasty; Below the knee arteries; Critical ischemia; Diabetic patients; Infragenicular; Tibial arteries.

\section{Introduction:}

It is well known that atherosclerotic involvement in diabetic patients with critical limb ischemia (CLI) mainly affects below-theknee (BTK) arteries, ${ }^{1}$ but the therapeutic efficacy of percutaneous transluminal angioplasty (PTA) in such patients has not been clearly defined. ${ }^{2}$ For this category of fragile patients world over, the features of the disease/morbidity, involving extended inflammation and tissue loss, make them somewhat reluctant to undergo re- vascularisation. ${ }^{3,4}$ However, increasing contemporary reports are to date proposing primary angioplasty as a feasible procedure in most diabetic subjects with optimal clinical results. ${ }^{5-8}$

Studies of PTA in CLI have involved very heterogeneous patient populations, and this limits our knowledge of the value of PTA in particular patient subsets. Many of the published studies included diabetic and nondiabetic patients, different stages of ischaemia (claudication, rest pain, and tissue loss) and 
PTA of above-the-knee (ATK) and below-theknee (BTK) vessels performed in the same setting. ${ }^{9-15}$

The purpose of this study was to assess the clinical success and the limb-salvage rates for infragenicular angioplasty as the initial treatment of critically ischemic lower limbs in diabetic patients.

\section{Materials and methods:}

From December 2006 to October 2008, 64 limbs in 54 diabetic patients were treated for critical limb ischemia at Ain Shams University Hospitals, and Nasr City Health Insurance Hospital. We included patients who satisfied the following parameters: (1) Patients who are known diabetics for more than 2 years; (2) Critical limb ischemia (Rutherford categories 4,5,6); (3) Infragenicular arterial disease with collateral distal refilling of at least one of the foot vessels on pre-procedural imaging studies; (4) Absence of concomitant supragenicular significant $(>30 \%)$ arterial stenosis. Patients with serum creatinine $>3.0$ were excluded.

Patient demographic data including risk factors were collected and tabulated. Clinical criteria including Rutherford category at baseline and during follow up were collected and analyzed. Lesion morphological criteria including lesion severity (occlusion or stenosis) and length were recorded during the intraprocedural initial angiographic cineloop. Periprocedural medications were acetylcysetine with good hydration at a rate of $0.5 \mathrm{ml} / \mathrm{Kg} / \mathrm{hr}$ normal saline for $6 \mathrm{hrs}$ before and after the procedure and intra-procedural 5000 units of unfractionated heparin. We used non ionic contrast medium (Ultravist). Post procedure, we initiated therapeutic low molecular weight heparin (LMWH) anticoagulation for $48 \mathrm{hrs}$ together with clopidogril loading dose (300mg), then statins (Atorvastatin; 20mg/day) and clopidogril ( $75 \mathrm{mg} /$ day) were to be continued on maintenance dose for 90 days.
Procedural tools were invariably, a 6-F introducing sheath, a 4-F angiographic catheter (Vertebral, Cordis, USA), 0.035 hydrophilic guidewire (Terumo, Japan), and a 0.014 guidewire (PT2, Boston scientific, USA), long tibial balloons (amphirion deep, Invatec, Italy) and stents when needed (Chromis deep, Invatec, Italy). Procedures were done in an antegrade approach under local anaesthesia in a dedicated vascular surgery room with a mobile $\mathrm{C}$-arm with vascular imaging capabilities.

Immediate technical success was defined as residual angiographic stenosis of $<30 \%$ of the target lesion with an inline flow in at least one tibial vessel down to the foot.

Post-procedure, any minor amputations needed were to be done within $48 \mathrm{hrs}$ of the procedure, together with recording of periprocedural adverse events.

Follow up was scheduled at 1 month, 3 months, 6 months, and 1 year following the procedure for: (1) Sustained clinical improvement based on Rutherford upward categorical shift with absence of rest pain and/or progressive tissue healing; (2) Haemodynamic outcome based on pulse volume recordings (PVRs) using Bidop3 ${ }^{\circledR}$ vascular testing system; (3) Freedom from major amputation.

\section{Results:}

Out of 156 patients who underwent percutaneous transluminal angioplasty (PTA) for critical limb ischemia (CLI) during our study period, only 54 patients with 64 critically ischemic limbs met our inclusion criteria and were included in our study. We studied 29 diabetic males and 25 diabetic females, with a mean age of 62 years, and a remarkable association of hypertension $(92.5 \%)$, ischemic heart disease $(88.8 \%)$, and renal impairment with serum creatinine $<3.0$ in $(26 \%)$. Table(1) summarises the patients' demographic data and risk factors. 
Table (1):Demographic data and risk factors.

\begin{tabular}{|l|c|}
\hline Total number of patients & $\mathrm{n}=54$ \\
\hline Number of limbs & $\mathrm{n}=64$ \\
\hline Males : Females & $29: 25$ \\
\hline Age (years) & $62(48-70)$ \\
\hline Hypertension & $92.5 \%(\mathrm{n}=50)$ \\
\hline Smoking & $70 \%(\mathrm{n}=38)$ \\
\hline Ischemic heart disease & $88.8 \%(\mathrm{n}=48)$ \\
\hline Renal impairment & $26 \%(\mathrm{n}=14)$ \\
\hline
\end{tabular}

The clinical stratification of our patients at time of enrolment in our study showed a nearly equal distribution between Rutherford categories 4, 5, and 6, with $28 \%$ of patients enrolled as Rutherford category 4 (rest pain), while $35 \%$ of patients were Rutherford category 5 (minor tissue loss), and $37 \%$ of patients were Rutherford category 6 (major tissue loss). Table(2) summarises the patients' clinical criteria at baseline.

\section{Table (2):Clinical criteria at baseline.}

\begin{tabular}{|c|c|}
\hline Treated limbs & $\mathrm{n}=64$ \\
\hline Rutherford 4 & $28 \%(\mathrm{n}=18)$ \\
\hline Rutherford 5 & $35 \%(\mathrm{n}=22)$ \\
\hline Rutherford 6 & $37 \%(\mathrm{n}=24)$ \\
\hline
\end{tabular}

We classified lesions in the treated limbs according to the target vessel to be treated which is the most likely to provide an inline flow down to the foot. This was done during the intraprocedural preliminary selective contrast injection at the level of the popliteal artery below the knee together with digital subtraction angiography (DSA) for proper visualization of the tibial vessels and careful differentiation between a tight stenosis and total occlusion. In case of the presence of a simultaneous stenotic and occlusive lesions, or 2 lesions of the same type but with varying lengths in the same target vessel, we classified the lesion according to the most severe lesion type. The peroneal artery was the most commonly treated artery with a $42 \%$ preponderance Figure(1), the posterior tibial artery was our target vessel in $35 \%$ of treated limbs, and lastly the anterior tibial vessel in 23\%. Table(3) summarises the lesion characteristics in our study population.
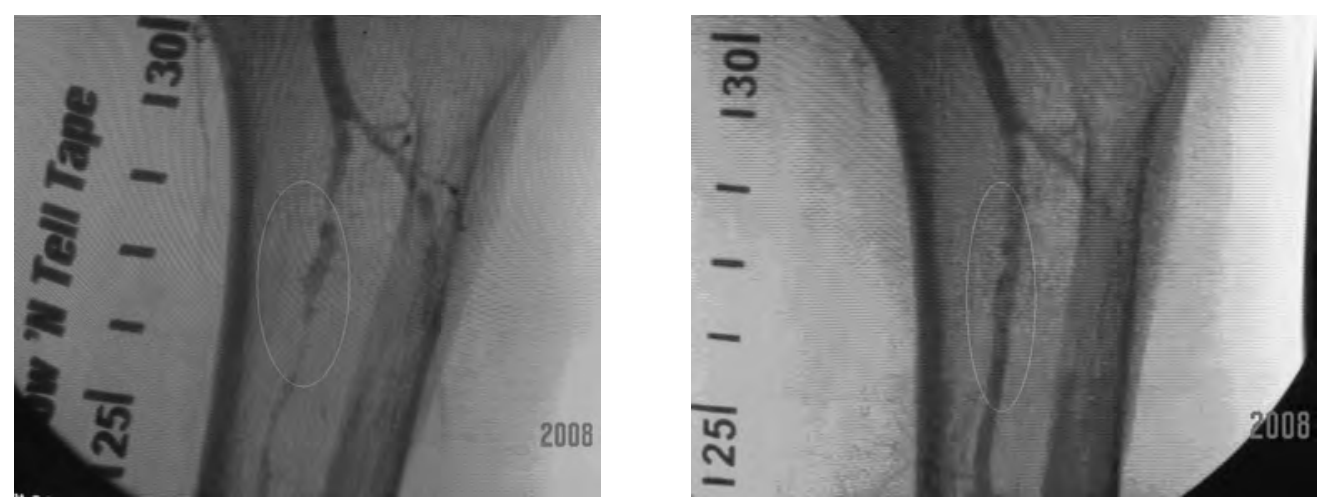

Figure (1): Showing pre and post angioplasty of the peroneal artery. 
Table (3): Lesion characteristics.

\begin{tabular}{|l|l|}
\hline Total Procedures & $\mathrm{n}=64$ \\
\hline Lesion Characteristics & \\
\hline Stenosis & $42 \%(\mathrm{n}=27)$ \\
\hline Mean stenotic length & $12 \mathrm{~cm}$ \\
\hline Occlusion & $58 \%(\mathrm{n}=37)$ \\
\hline Mean occlusion length & $17 \mathrm{~cm}$ \\
\hline Target vessel & \\
\hline Anterior tibial & $23 \%(\mathrm{n}=15)$ \\
\hline Posterior tibial & $35 \%(\mathrm{n}=22)$ \\
\hline Peroneal & $42 \%(\mathrm{n}=27)$ \\
\hline
\end{tabular}

The technical characteristics of the procedure regarding guidewire passage plane through the lesion were determined by the operator according to the guidewire-lesion interaction under fluoroscopic guidance and were documented in the procedure details sheet. Out of 64 procedures we had 20(31\%) vessels treated by a transluminal approach, 9(14\%) vessels treated by a subintimal approach with a clear entry and re-entry sites and 35(55\%) vessels treated by a combined transluminal and subintimal passage of the wire. We needed to deploy stents only in 4 cases due to ostial residual stenosis or occlusive dissections, 2 of which were in the peroneal - tibioperoneal segment and the other 2 were in the anterior tibial artery. Table(4) summarises the procedure technical characteristics.

Table (4): Procedure technical characteristics.

\begin{tabular}{|l|c|}
\hline Total Procedures & $\mathrm{n}=64$ \\
\hline Transluminal & $31 \%(\mathrm{n}=20)$ \\
\hline Subintimal & $14 \%(\mathrm{n}=9)$ \\
\hline Combined & $55 \%(\mathrm{n}=35)$ \\
\hline Tibial stents & $6 \%(\mathrm{n}=4)$ \\
\hline
\end{tabular}

We achieved immediate technical success, which was defined as residual angiographic stenosis of $<30 \%$ of the target lesion with an inline flow in at least one tibial vessel down to the foot, in $60(94 \%)$ of our procedures with only 4 failures in 4 patients in whom all of the three leg vessels were totally occluded and the reasons for failures were an inability to cross a highly calcified chronic total occlusion. These patients were not suitable for surgical revascularization and had primary below knee amputations. Table(5) summarises the immediate technical success data.

Table (5): Immediate technical success.

\begin{tabular}{|l|c|}
\hline Total Procedures & $\mathrm{n}=64$ \\
\hline Immediate success & $94 \%(\mathrm{n}=60)$ \\
\hline Stenosis & $(\mathrm{n}=27 / 27) 100 \%$ \\
\hline Occlusion & $(\mathrm{n}=33 / 37) 89 \%$ \\
\hline
\end{tabular}


There were 4 cases of post procedure groin haematomas that did not require any special treatment, only one case of myocardial infarction 2 days following the procedure after she had a toe amputation, no renal failure with post procedure raising creatinine, and one mortality during the first month due to intracranial haemorrhage. Table(6) summarises the periprocedural adverse events and 30 day mortality.

Table (6): Periprocedural adverse events and 30 day mortality.

\begin{tabular}{|l|l|}
\hline Groin haematoma & $\mathrm{n}=4$ \\
\hline Cardiac event & $\mathrm{n}=1$ \\
\hline Renal failure & $\mathrm{n}=0$ \\
\hline 30 day mortality & $\mathrm{n}=1$ \\
\hline
\end{tabular}

We observed immediate clinical healing together with improved pulse volume improvement in 60(94\%) limbs based on Rutherford upward categorical shift with absence of rest pain and/or progressive tissue recordings (PVRs). Table(7) summarises the immediate clinical improvement.

Table (7): Immediate clinical improvement.

\begin{tabular}{|l|l|}
\hline Upward shift to Rutherford category -3 & $94 \%(\mathrm{n}=60)$ \\
\hline Improved (PVRs) & $94 \%(\mathrm{n}=60)$ \\
\hline
\end{tabular}

Sustained clinical improvement based on Rutherford upward categorical shift with absence of rest pain and/or progressive tissue healing during the follow up period of our study, is represented by the Kaplan-Meier curve shown in Figure(2). It shows a sustained clinical improvement of $100 \%, 95 \%, 89 \%$, and $84 \%$ at $1,3,6$, and 12 months respectively. Table $(8)$ shows the number of patients at risk at the beginning of each interval after exclusion of patients who were censored during follow up or those who reached the end point.

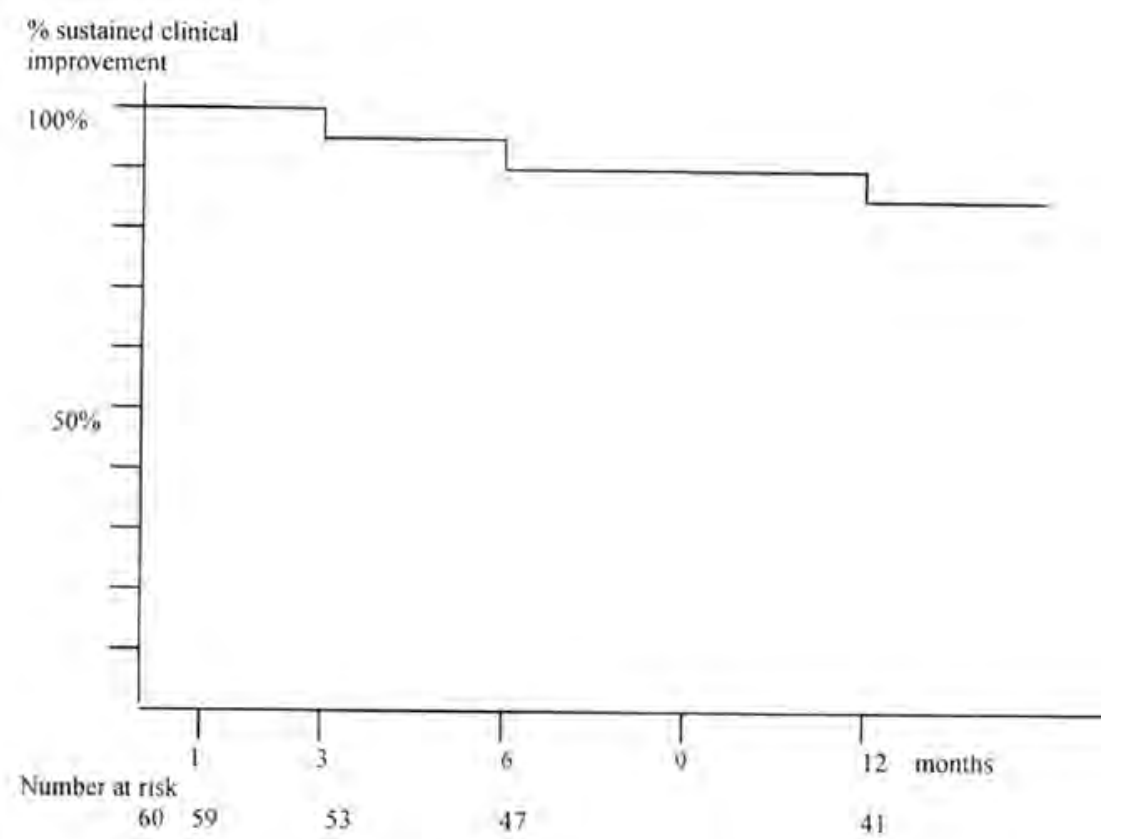

Figure (2): Kaplan-Meier curve showing sustained clinical improvement. 
Table (8): Kaplan-Meier data of sustained clinical improvement.

\begin{tabular}{|c|c|c|c|c|c|c|}
\hline $\begin{array}{c}\text { Interval } \\
\text { (months) }\end{array}$ & $\begin{array}{c}\text { Number } \\
\text { at risk } \\
\text { at the } \\
\text { start of } \\
\text { interval }\end{array}$ & $\begin{array}{c}\text { Censored } \\
\text { during } \\
\text { interval }\end{array}$ & $\begin{array}{c}\text { Number } \\
\text { at risk } \\
\text { at the } \\
\text { end of } \\
\text { interval }\end{array}$ & $\begin{array}{c}\text { Number } \\
\text { reached } \\
\text { an } \\
\text { endpoint } \\
\text { at the end } \\
\text { of interval }\end{array}$ & $\begin{array}{c}\text { Proportion } \\
\text { surviving } \\
\text { this } \\
\text { interval }\end{array}$ & $\begin{array}{c}\text { Cumulative } \\
\text { survival } \\
\text { at the end } \\
\text { of interval }\end{array}$ \\
\hline $0-1$ & 60 & 1 & 59 & 0 & $59 / 59$ & 1.0 \\
\hline $1-3$ & 59 & 3 & 56 & 3 & $53 / 56$ & $1.0 * 0.95=0.95$ \\
\hline $3-6$ & 53 & 3 & 50 & 3 & $47 / 50$ & $1.0 * 0.95 * 0.94=0.89$ \\
\hline $6-12$ & 47 & 4 & 43 & 2 & $41 / 43$ & $1.0 * 0.95 * 0.94 * 0.95=0.84$ \\
\hline
\end{tabular}

Haemodynamic outcome based on pulse volume recordings (PVRs), is represented by the Kaplan-Meier curve shown in Figure(3). It shows a haemodynamic improvement of $96 \%, 89 \%, 79 \%$, and $60 \%$ at $1,3,6$, and 12 months respectively. $\operatorname{Table}(\mathbf{9})$ shows the number of patients at risk at the beginning of each interval after exclusion of patients who were censored during follow up or those who reached the end point.

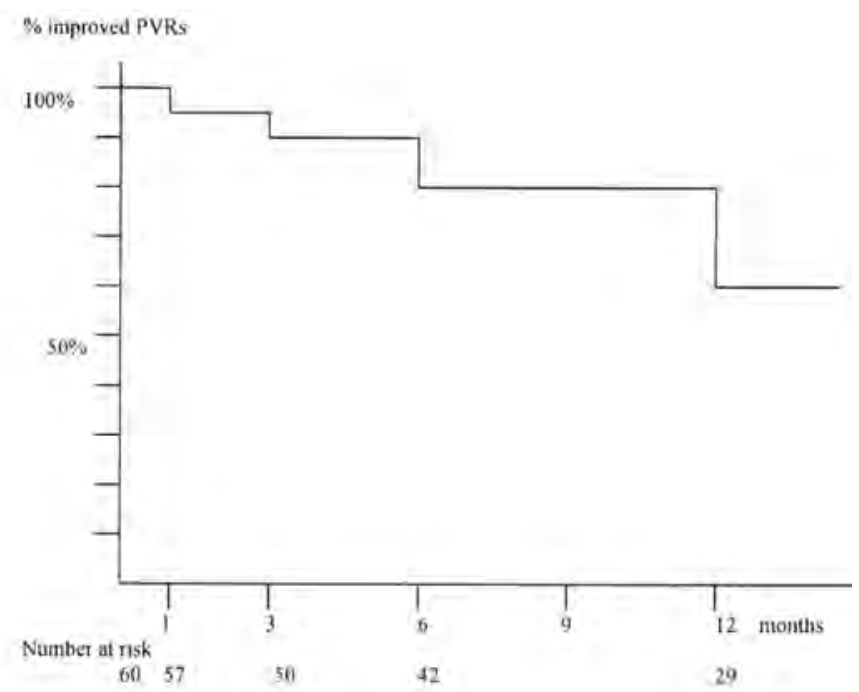

Figure (3): Kaplan-Meier curve showing haemodynamic outcome.

Table (9): Kaplan-Meier data of haemodynamic outcome.

\begin{tabular}{|c|c|c|c|c|c|c|}
\hline $\begin{array}{c}\text { Interval } \\
\text { (months) }\end{array}$ & $\begin{array}{c}\text { Number } \\
\text { at risk } \\
\text { at the } \\
\text { start of } \\
\text { interval }\end{array}$ & $\begin{array}{c}\text { Censored } \\
\text { during } \\
\text { interval }\end{array}$ & $\begin{array}{c}\text { Number } \\
\text { at risk } \\
\text { at the } \\
\text { end of } \\
\text { interval }\end{array}$ & $\begin{array}{c}\text { Number } \\
\text { reached } \\
\text { an } \\
\text { endpoint } \\
\text { at the end } \\
\text { of interval }\end{array}$ & $\begin{array}{c}\text { Proportion } \\
\text { surviving } \\
\text { this } \\
\text { interval }\end{array}$ & $\begin{array}{c}\text { Cumulative } \\
\text { survival } \\
\text { at the end } \\
\text { of interval }\end{array}$ \\
\hline $0-1$ & 60 & 1 & 59 & 2 & $57 / 59$ & 0.966 \\
\hline $1-3$ & 57 & 3 & 54 & 4 & $50 / 54$ & $0.966 * 0.925=0.893$ \\
\hline $3-6$ & 50 & 3 & 47 & 5 & $42 / 47$ & $0.966 * 0.925 * 0.893=0.797$ \\
\hline $6-12$ & 42 & 4 & 38 & 9 & $29 / 38$ & $0.966 * 0.925 * 0.893 * 0.763=0.6$ \\
\hline
\end{tabular}


Freedom from major amputation during the follow up period of our study, is represented by the Kaplan-Meier curve shown in Figure(4). It shows a limb salvage rate of $100 \%, 95 \%$, $89 \%$, and $84 \%$ at $1,3,6$, and 12 months respectively. Table(10) shows the number of patients at risk at the beginning of each interval after exclusion of patients who were censored during follow up or those who reached the end point.

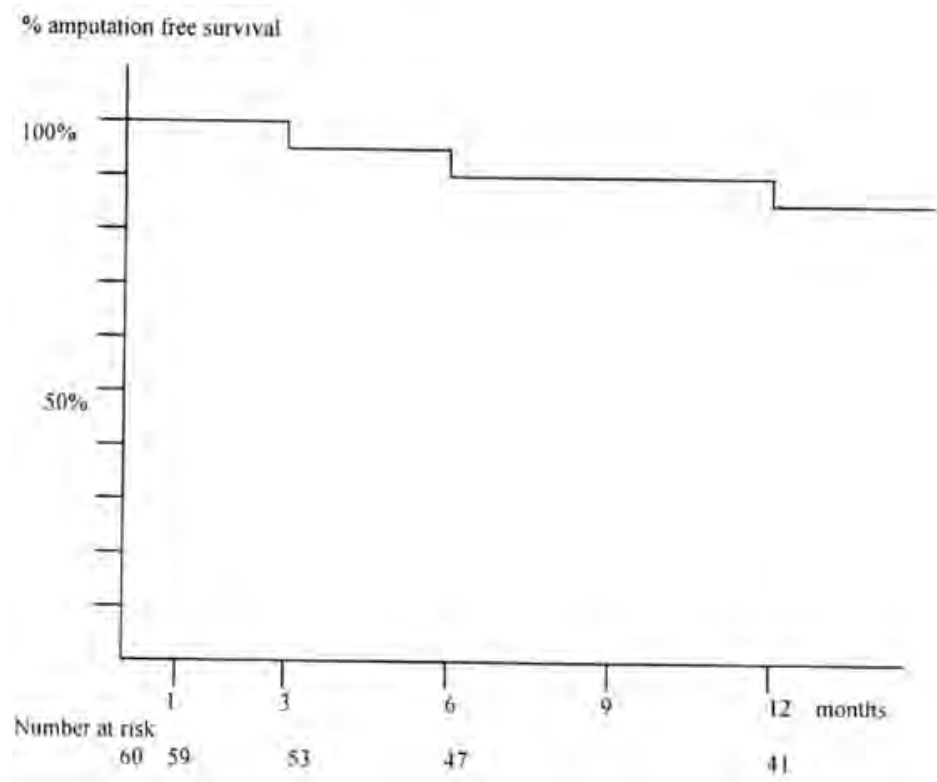

Figure (4): Kaplan-Meier curve showing amputation free survival.

Table (10): Kaplan-Meier data of amputation free survival.

\begin{tabular}{|c|c|c|c|c|c|c|}
\hline $\begin{array}{c}\text { Interval } \\
\text { (months })\end{array}$ & $\begin{array}{c}\text { Number } \\
\text { at risk } \\
\text { at the } \\
\text { start of } \\
\text { interval }\end{array}$ & $\begin{array}{c}\text { Censored } \\
\text { during } \\
\text { interval }\end{array}$ & $\begin{array}{c}\text { Number } \\
\text { at risk } \\
\text { at the } \\
\text { end of } \\
\text { interval }\end{array}$ & $\begin{array}{c}\text { Number } \\
\text { reached } \\
\text { an } \\
\text { endpoint } \\
\text { at the end } \\
\text { of interval }\end{array}$ & $\begin{array}{c}\text { Proportion } \\
\text { surviving } \\
\text { this } \\
\text { interval }\end{array}$ & $\begin{array}{c}\text { Cumulative } \\
\text { survival } \\
\text { at the end } \\
\text { of interval }\end{array}$ \\
\hline $0-1$ & 60 & 1 & 59 & 0 & $59 / 59$ & 1.0 \\
\hline $1-3$ & 59 & 3 & 56 & 3 & $53 / 56$ & $1.0 * 0.95=0.95$ \\
\hline $3-6$ & 53 & 3 & 50 & 3 & $47 / 50$ & $1.0 * 0.95 * 0.94=0.89$ \\
\hline $6-12$ & 47 & 4 & 43 & 2 & $41 / 43$ & $1.0 * 0.95 * 0.94 * 0.95=0.84$ \\
\hline
\end{tabular}

\section{Discussion:}

Bypass surgery using outflow vessels in the distal ankle and foot is considered the standard of care in patients with CLI due to BTK-vessel disease. ${ }^{16}$ However, it needs a good vein conduit and at least one open foot artery, and is associated with $0.9 \%$ perioperative mortality, $3.0 \%$ myocardial infarction or acute congestive heart failure, and $6.6 \%$ early re-operation for graft thrombosis, postoperative bleeding or infection. ${ }^{17}$ For these reasons, infrapopliteal PTA is currently proposed as the primary treatment for CLI in patients with ischaemic diabetic foot. ${ }^{9,13-15,18}$

Although many published papers have described interesting findings concerning the efficacy of the endovascular treatment of peripheral artery disease, these studies have not involved carefully selected patient populations as diabetics or appropriately stratified the level of atherosclerotic involvement. Thus it was not clear whether the infragenicular PTA results in the diabetic patient population is genuine or simply the 
result of improved outflow due to concomitant above the knee procedures. ${ }^{19-22}$

We conducted our study on a selected patient population of diabetic patients with isolated infragenicular arterial disease causing critical limb ischemia in order to precisely evaluate the clinical outcomes of PTA in diabetic patients with isolated BTK-vessel involvement.

Our studied population consisted of a very homogeneous group of predominantly male patients with a mean age of 62 years, and a remarkable association of hypertension, and ischemic heart disease with infragenicular arterial involvement with a mean diseased stenotic length of $12 \mathrm{~cm}$ and a mean occlusive segment length of $17 \mathrm{~cm}$. However, despite the severity of the disease, the successful endovascular procedures led to optimal followup outcomes.

The limb salvage rate at one year was $84 \%$ despite a one year objective improvement of pulse volume recordings (PVRs) of 60\%. This discrepancy probably reflects the fact that longterm complete patency of the treated vessel is less important in such patients than in those with coronary, carotid or renal arterial disease: the re-canalisation temporarily increases blood flow to the foot and has a positive effect in eradicating infection and healing ulcers and surgical wounds. As foot tissue healing reduces oxygen demand, less blood flow is generally required to maintain tissue integrity and keep the limb asymptomatic. ${ }^{10,23}$ Although this population of patients are technically challenging, our results support the role of PTA as the therapeutic option for CLI diabetic patients with infragenicular arterial disease.

The main finding of our study is that primary infragenicular angioplasty for limb salvage in the diabetic patient population represents an efficacious method to improve wound healing in critically ischemic limbs, and should be the first treatment option in all patients with CLI who would otherwise be offered distal bypass surgery or amputation, taking into consideration the fragile nature and co-morbidities in such selected patient population.

\section{References:}

1- Diehm N, Shan A, Silvestro A, Do DD, Dick F, Schmidli J, et al: Association of cardiovascular risk factors with pattern of lower limb atherosclerosis in 2659 patients undergoing angioplasty. Eur J Vasc Endovasc Surg 2006; 31: 59-63.

2- Capek P, McLean GK, Berkowitz HD: Femoropopliteal angioplasty: Factors influencing long-term success. Circulation 1991; 83 (Suppl.2): 170-180.

3- Hafner J, Schaad I, Schneider E, Seifert B, Burg G, Cassina PC: Leg ulcers in peripheral arterial disease (arterial leg ulcers): Impaired wound healing above the threshold of chronic critical limb ischemia. J Am Acad Dermatol 2000; 43(6): 10011008.

4- Calle-Pascual AL, Duran A, Diaz A, Monux G, Serrano FJ, de la Torre NG, et al: Comparison of peripheral reconstruction in diabetic and non-diabetic patients: A prospective clinic based study. Diabetes Res Clin Pract 2001; 53(2): 129136.

5- Norgreen L, Hiatt WR, Dormandy JA, Nehler MR, Harris KA, Fowkes FGR- on behalf of the TASC II Working Group: Inter-society consensus for the management of peripheral arterial disease (TASC II). Eur J Vasc Endovasc Surg 2007; 33 (Suppl.1): 32-55.

6- Haider SN, Kavanagh EG, Forlee M, Colgan MP, Madhavan P, Moore DJ, et al: Two-year outcome with preferential use of infra-inguinal angioplasty for critical ischemia. J Vasc Surg 2006; 43(3): 504512.

7- Dick F, Diehm N, Galimanis A, Husmann M, Schmidli J, Baumgartner I: Surgical or endovascular revascularization in patients with critical limb ischemia: Influence of diabetes mellitus on clinical outcome. J Vasc Surg 2007; 45: 751-761.

8- Lazaris AM, Tsiamis AC, Fishwick G, Bolia A, Bell PRF: Clinical outcome of primary infrainguinal subintimal angioplasty in diabetic patients with critical lower limb ischemia. J Endovasc Ther 2004; 11: 447-453. 
9- Bosiers M, Hart JP, Deloose K, Verbist J, Peeters P: Endovascular therapy as the primary approach for limb salvage in patients with critical limb ischemia: Experience with 443 infrapopliteal procedures. Vascular 2006; 14(2): 63-69.

10-Soder HK, Manninen HI, Jaakkola P, Matsi PJ, Rasanen HT, Kaukanen E, et al: Prospective trial of infrapopliteal artery balloon angioplasty for critical limb ischemia: Angiographic and clinical results. J Vasc Interv Radiol 2000; 11: 1021-1031.

11-Dorros G, Jaff MR, Murphy KJ, Mathiak L: The acute outcome of tibioperoneal vessel angioplasty in 417 cases with claudication and critical limb ischemia. Cathet Cardiovasc Diagn 1998; 45: 251-256.

12-Boyer L, Therre T, Garcier JM, Perez N, Ravel A, Privat C, et al: Infrapopliteal percutaneous transluminal angioplasty for limb salvage. Acta Radiol 2000; 41: 73 77.

13-Dorros G, Jaff MR, Dorros AM, Mathiak LM, He T: Tibioperoneal (outflow lesion) angioplasty can be used as primary treatment in 235 patients with critical limb ischemia: Five-year follow-up. Circulation 2001; 104: 2057-2062.

14-Brillu C, Picquet J, Villapadierna F, Papon X, L'Hoste P, Jousset Y, et al: Percutaneous transluminal angioplasty for management of critical ischemia in arteries below the knee. Ann Vasc Surg 2001; 15: 175-181.

15-Schillinger M, Exner M, Mlekusch W, Haumer M, Rumpold H, Ahmadi R, et al: Endovascular revascularization below the knee: 6-month results and predictive value of C-reactive protein level. Radiology 2003; 227: 419-425.

16-Aulivola B, Pomposelli FB: Dorsalis pedis, tarsal and plantar artery bypass. $J$ Cardiovasc Surg 2004; 45: 203-212.
17-Pomposelli FB, Kansal N, Hamdan AD, Belfield A, Sheahan M, Campbell DR, et al: A decade of experience with dorsalis pedis artery bypass: Analysis of outcome in more than 1000 cases. J Vasc Surg 2003; 37: 307-315.

18-Faglia E, Dalla Paola L, Clerici G, Clerissi J, Graziani L, Fusaro M, et al: Peripheral angioplasty as the first-choice revascularization procedure in diabetic patients with critical limb ischemia: Prospective study of 993 consecutive patients hospitalized and followed between 1999 and 2003. Eur J Vasc Endovas Surg 2005; 29: 620-627.

19-Fraser SC, al-Kutoubi MA, Wolfe JH: Percutaneous transluminal angioplasty of the infrapopliteal vessels: The evidence. Radiology 1996; 200: 33.

20-Karch LA, Mattos MA, Henretta JP, McLafferty RB, Ramsey DE, Hodgson KJ: Clinical failure after percutaneous transluminal angioplasty of the superficial femoral and popliteal arteries. J Vasc Surg 2000; 31(5): 880-887.

21-Wolfle KD, Bruijnen H, Reeps C, Reutemann S, Wack C, Campbell P, et al: Tibioperoneal arterial lesions and critical foot ischaemia: Successful management by the use of short vein grafts and percutaneous transluminal angioplasty. Vasa 2000; 29(3): 207-214.

22-Conrad MF, Cambria RP, Stone DH, Brewster DC, Kwolek CJ, Watkins MT, et al: Intermediate results of percutaneous endovascular therapy of femoropopliteal occlusive disease: A contemporary series. J Vasc Surg 2006; 44(4): 762-769.

23-Bakal CW, Cynamon J, Sprayregen S: Infrapopliteal percutaneous transluminal angioplasty: What we know. Radiology 1996; 200: 33-36. 